\title{
Management of Powdery Mildew Disease in Sesamum
}

\author{
V. Madhuri* and G. Karuna Sagar \\ Agricultural Research Station, Utukur, Kadapa - 516 003, Acharya N.G. Ranga Agricultural \\ University, Guntur, Andhra Pradesh, India \\ *Corresponding author
}

\section{A B S T R A C T}

\section{Keywords \\ Sesame (Sesamum indicum L.), C: B ratio \\ Article Info \\ Accepted: \\ 24 August 2018 \\ Available Online: \\ 10 September 2018}

A field experiment was conducted during rabi 2014-16 by using seven different fungicides in which all the treatment fungicides were found to be significantly superior over control in reducing the disease incidence and increasing grain yield during rabi 2014, 2015 and 2016. Pooled data revealed that $\mathrm{T}_{1}$ i.e. carbendazim @ $0.1 \%$ found to be more effective by recording the PDI of $20.56 \%$, seed yield of $604 \mathrm{~kg} / \mathrm{ha}$ and C: B ratio of 1:1.36 followed by wettable sulphur $\left(\mathrm{T}_{2}\right) @ 0.3 \%$ with PDI of $22.98 \%$, seed yield of $598 \mathrm{~kg} / \mathrm{ha}$ and C: B ratio of 1:1.26.

\section{Introduction}

Sesame (Sesamum indicum L.) is one of the oldest important oil seed crop and is under cultivation from ancient times. India contributes the highest sesame acreage of above 17.73 lakh hectares with the production 8 lakh tonnes and productivity of 445 $\mathrm{kg} /$ hectare. The low productivity is attributed to poor crop management and exposure of the crop to a number of biotic and abiotic stresses. It is also known as generally, til, popularly as "Queen of Oilseeds" due to its stabilized keeping quality contributed by high degree of resistance to oxidation (Bedigian and Harlan, 1986).

The area and production of sesame crop is gradually declining in the traditional areas.
Despite the potential for increasing the production and productivity of sesame, there are a number of challenges inhibiting sesame production and productivity. Among the many production constraints, the most important include lack of improved cultivars and a poor seed supply system.

In addition, there are severe biotic stresses, such as root rot /stem rot (Macrophomina phaseolina) (Tassi) Goid, Phyllody (a Mycoplasma, like organism), Powdery mildew (Oidium erysiphoides), Alternaria leaf spot (Alternaria sesami) and cercospora leaf spot (Cercospora sesami). Diseases are reported to cause a considerable yield loss elsewhere in the world. Sesame diseases cause damage to seed, seedling, root, stem as well as foliage resulting in significant loss. 
Powdery mildew and leaf spots are important fungal diseases which were reported to cause a yield loss of $45 \%-100 \%$ and $22-53 \%$, respectively during severe epidemics. However, regardless of the economic importance of these diseases, there is no any effort made for its management. Therefore, this experiment is intended to evaluate some fungicides and to recommend for the end users i.e farmers which will take us one step forward in the management of this disease. The main objective of the experiment was to identify the most effective and economical fungicide for the management of powdery mildew disease in sesamum.

\section{Materials and Methods}

\section{Description of experimental site}

This experiment was conducted for three years during rabi 2014-2016 at Agricultural Research Station, Utukur, Kadapa.

\section{Treatments and design}

The experiment was executed by using Randomized Block Design with seven treatments and three replications. Local Sesame cultivar (Gowri) was used to evaluate the effectiveness of different fungicides against Powdery mildew disease of sesame. A plot size was $4.5 \mathrm{~m} \times 3.0 \mathrm{~m}$ and replication spacing of $1.0 \mathrm{~m}$ was maintained. Fungicides sprayings were started immediately after the initial appearance of the symptoms.

\section{About the disease}

Powdery mildew caused by Oidium erysiphae. It is the most important disease of sesame, occurring widely throughout India and causes substantial qualitative and quantitative loss to the crop. It occurs in epidemic scale under heavy rainfall condition followed by low night temperature and high humidity. It appears at flowering to capsule formation stage as small patches of white powder on upper side and occasionally on lower surface of leaves. Defoliation of severely infected plant occurs before maturity. Powdery mildew causes yield losses ranging from 25 to $50 \%$ depending upon the level of incidence an average yield loss of $45 \%$ has been reported to be caused by powdery mildew.

A powdery mildew disease development was rated based on a scoring scale developed for the disease on a 0 - 5 scale.

The incidence of powdery mildew was recorded on a 0-5 scale (Anonymous, 2015).

The crop was raised as per the agronomic practices given in the Crop Production Guide and observations of disease incidence/severity were recorded one week after spraying and yields were recorded at the time of harvesting.

The grain yield was recorded and C: B ratio was worked out. Statistical analysis of the experiment was performed.

\section{Results and Discussion}

It is evident from Table 3 that all the treatments were found to be significantly superior over control in reducing the disease incidence and increasing grain yield during rabi 2014, 2015 and 2016. Of which $\mathrm{T}_{1}$ i.e foliar spray of carbendazim @1.g/1 followed by wettable sulphur @ $0.3 \%$ were found to be significantly effective by recording the minimum incidence of powdery mildew and highest seed yields during rabi 2014, 2015 \& 2016 (Table 1-5).

As per Table 4 i.e. pooled data of efficacy of fungicides on incidence of powdery mildew and seed yields during rabi 2014, 2015 and 2016, $\mathrm{T}_{1}$ i.e. carbendazim @ $0.1 \%$ found to be more effective by recording the PDI of 20.56 
$\%$, seed yield of $604 \mathrm{~kg} / \mathrm{ha}$ and $\mathrm{C}$ : B ratio of @ $0.3 \%$ with PDI of $22.98 \%$, seed yield of 1:1.36 followed by $\mathrm{T} 3$ wettable sulphur $598 \mathrm{~kg} / \mathrm{ha}$ and C: B ratio of 1:1.26 (Table 4).

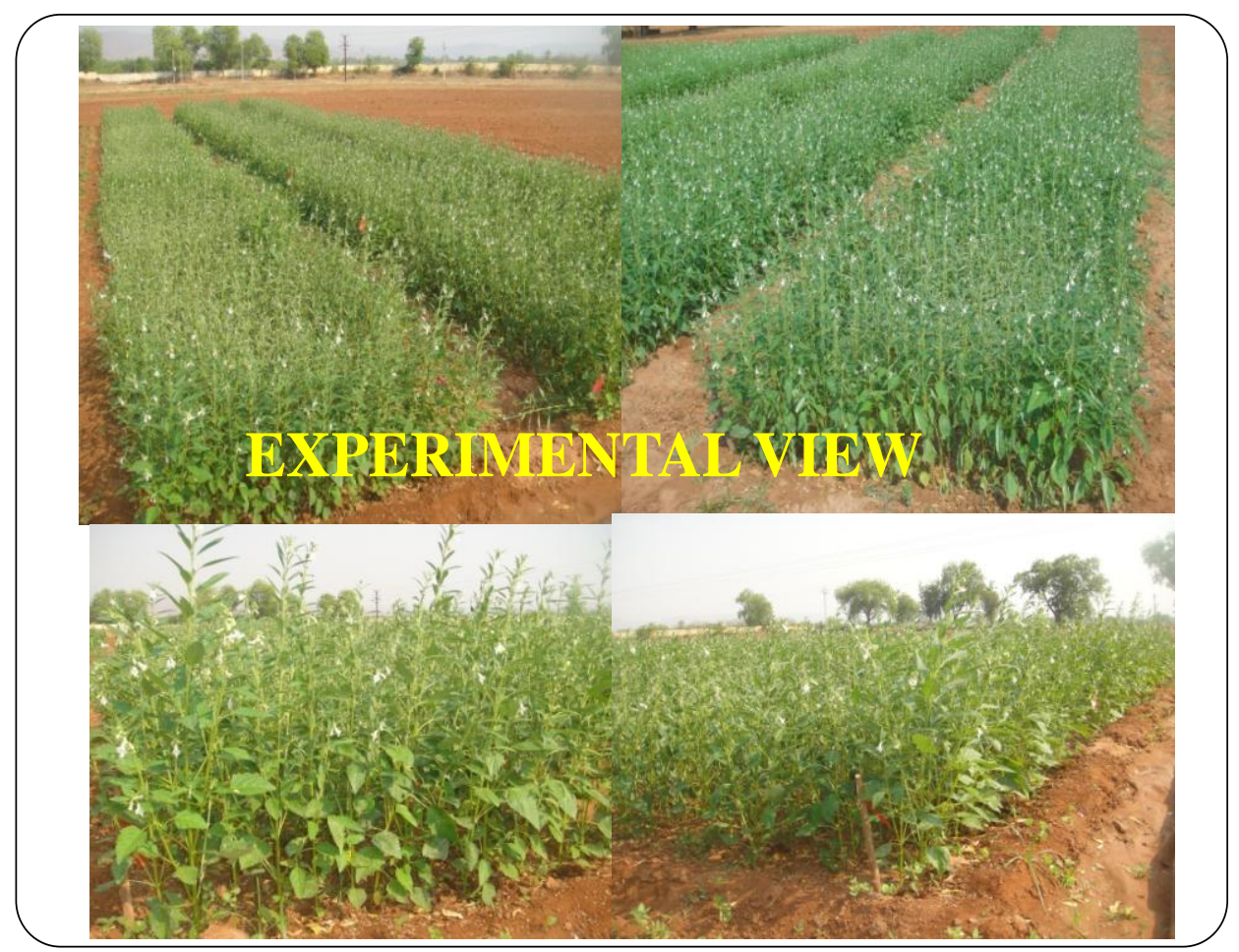

Table.1 List of fungicides

\begin{tabular}{|c|c|c|}
\hline S. No & Name of the treatment & Dosage of the fungicide \\
\hline $\mathrm{T}_{1}$ & Carbendazim & $0.1 \%$ \\
\hline $\mathrm{T}_{2}$ & Wettable sulphur & $0.3 \%$ \\
\hline $\mathrm{T}_{3}$ & Hexaconazole & $0.2 \%$ \\
\hline $\mathrm{T}_{4}$ & Myclobutanil & $0.1 \%$ \\
\hline $\mathrm{T}_{5}$ & Propiconazole & $0.1 \%$ \\
\hline $\mathrm{T}_{6}$ & Thiophante methyl & $0.1 \%$ \\
\hline $\mathrm{T}_{7}$ & Untreated Control & - \\
\hline
\end{tabular}

Table.2 Disease scoring scale for powdery mildew disease of sesame

\begin{tabular}{|c|}
\hline Disease grade \\
\hline $\mathbf{0}$ \\
\hline $\mathbf{1}$ \\
\hline $\mathbf{2}$ \\
\hline $\mathbf{3}$ \\
\hline $\mathbf{4}$ \\
\hline $\mathbf{5}$ \\
\hline
\end{tabular}

\section{Grade description}

No infection (immune)

$1-10 \%$ of leaf area infected (highly resistant)

$10-25 \%$ of leaf area infected (moderately resistant)

$26-50 \%$ of leaf area infected (moderately susceptible)

$51-70 \%$ of leaf area infected (susceptible)

$>70 \%$ of leaf area infected (highly susceptible) 
Table.3 Management of powdery mildew disease in sesamum during rabi 2014, 2015 \& 2016

\begin{tabular}{|c|c|c|c|c|c|c|c|}
\hline & Name of the treatment & \multicolumn{3}{|c|}{ Per cent Disease Index (PDI) \% } & \multicolumn{3}{|c|}{ Pod yield (kg/ha) } \\
\hline & & 2014 & 2015 & 2016 & 2014 & 2015 & 2016 \\
\hline $\mathbf{T}_{1}$ & Carbendazim @0.1\% & $11.47(19.74)$ & $24.83(29.75)$ & $25.55(30.29)$ & 655 & 534 & 604 \\
\hline$\overline{T_{2}}$ & Wettable sulphur@0.3\% & $14.40(22.30)$ & $25.55(30.43)$ & $28.89(32.50)$ & 628 & 527 & 579 \\
\hline$\overline{T_{3}}$ & Hexaconazole@0.2\% & $28.00(31.93)$ & $38.54(38.21)$ & $41.33(40.01)$ & 520 & 429 & 497 \\
\hline $\mathbf{T}_{4}$ & Myclobutanil@0.1\% & $17.40(24.63)$ & $31.55(34.12)$ & $33.89(35.60)$ & 604 & 484 & 523 \\
\hline $\mathbf{T}_{5}$ & Propiconazole @ $0.1 \%$ & $26.00(30.65)$ & $37.00(37.46)$ & $35.55(36.59)$ & 563 & 437 & 507 \\
\hline $\mathrm{T}_{6}$ & Thiophante methyl @0.1\% & 46.67(43.09) & $43.83(41.45)$ & $49.00(44.43)$ & 407 & 406 & 409 \\
\hline $\mathbf{T}_{7}$ & Control & $69.00(56.22)$ & $51.25(45.76)$ & $58.33(49.80)$ & 245 & 329 & 314 \\
\hline & CD@ @ \% & 4.84 & 6.86 & 3.60 & 26.36 & 17.64 & 19.64 \\
\hline & SEm \pm & 1.57 & 2.22 & 1.17 & 8.56 & 5.72 & 6.37 \\
\hline & $\mathrm{CV}$ & 8.95 & & & 2.84 & 2.41 & 2.25 \\
\hline
\end{tabular}

Figures in parentheses are angular transformed values

Table.4 Pooled data of efficacy of fungicides on powdery mildew in sesamum during rabi 2014, 2015 and 2016

\begin{tabular}{|c|c|c|c|c|}
\hline & Name of the Treatment & Per cent Disease Index (PDI) \% & Seed yield (kg/ha) & Cost Benefit ratio \\
\hline $\mathbf{T}_{1}$ & Carbendazim @ $0.1 \%$ & $20.56(26.95)$ & 604 & $1: 1.36$ \\
\hline $\mathbf{T}_{2}$ & Wettable sulphur @ $0.3 \%$ & $22.98(28.64)$ & 598 & $1: 1.26$ \\
\hline $\mathbf{T}_{\mathbf{3}}$ & Hexaconazole@0.2\% & $35.20(36.39)$ & 482 & $1: 0.93$ \\
\hline $\mathbf{T}_{5}$ & Propiconazole@0.1\% & $31.68(34.25)$ & 532 & $1: 0.90$ \\
\hline $\mathrm{T}_{6}$ & Thiophante methyl @0.1\% & $46.49(42.98)$ & 407 & $1: 0.55$ \\
\hline & SEm \pm & 0.53 & 6.09 & - \\
\hline & $\mathrm{CV}$ & & 2.10 & - \\
\hline
\end{tabular}

Figures in parentheses are angular transformed values 
Table.5 Economics of different fungicides evaluated for powdery mildew management in sesamum during rabi, 2014,2015 and 2016

\begin{tabular}{|c|c|c|c|c|c|c|c|}
\hline & Name of the Treatment & $\begin{array}{l}\text { Seed } \\
\text { yield } \\
\text { (kg/ha) }\end{array}$ & $\begin{array}{l}\text { Gross } \\
\text { returns } \\
\left(\mathbf{h a}^{-1}\right)\end{array}$ & $\begin{array}{c}\text { Cost of } \\
\text { cultivation } \\
\left(\mathrm{ha}^{-1}\right)\end{array}$ & $\begin{array}{l}\text { Cost of the } \\
\text { treatment } \\
\text { including }\end{array}$ & $\begin{array}{c}\text { Net } \\
\text { returns } \\
\left(\text { ha }^{-1}\right)\end{array}$ & $\begin{array}{c}\text { Cost } \\
\text { benefit } \\
\text { ratio }\end{array}$ \\
\hline & & & & & $\begin{array}{c}\overline{\text { labour charges }} \\
\left(\mathrm{ha}^{-1}\right)\end{array}$ & & \\
\hline $\mathbf{T}_{1}$ & Carbendazim @0.1\% & 604 & 39,260 & 16,620 & 620 & 22,640 & $1: 1.36$ \\
\hline $\mathbf{T}_{2}$ & Wettable sulphur@0.3\% & 598 & 37,635 & 16,640 & 640 & 20,995 & $1: 1.26$ \\
\hline$\overline{\mathbf{T}_{3}}$ & Hexaconazole@0.2\% & 482 & 32,955 & 17,000 & 1000 & 15,955 & $1: 0.93$ \\
\hline $\mathbf{T}_{4}$ & Myclobutanil @ $0.1 \%$ & 579 & 33,995 & 17,300 & 1300 & 16,695 & $1: 0.96$ \\
\hline $\mathbf{T}_{\mathbf{5}}$ & Propiconazole@0.1\% & 532 & 32,305 & 16,925 & 925 & 15,380 & $1: 0.90$ \\
\hline $\mathrm{T}_{6}$ & Thiophante methyl @ $0.1 \%$ & 407 & 26,585 & 17,100 & 1100 & 9,485 & $1: 0.55$ \\
\hline $\mathbf{T}_{7}$ & Control & 306 & 20,475 & 16,000 & - & 4,475 & $1: 0.27$ \\
\hline
\end{tabular}




\section{Conclusion and Recommendation}

Sesame (Sesamum indicum L.) is an important oilseed crop produced in the tropical and subtropical parts of the world. And farmers of this area are producing the crop intensively due to its high market value. However, farmers are suffering from a huge productivity loss due to Powdery mildew disease of Sesame. This disease is challenging the crop productivity putting its production highly under its potential. A similar observation was made by Teshome (2018) against sesame powdery mildew. To tackle this problem, different fungicides supposed to control/reduce the diseases are evaluated in the present study. All the evaluated fungicides have shown effectiveness as compared to the control plot against the disease.

However, out of the all the tested fungicides, carbendazim@0.1\% have showed better controlling potential against the disease. Therefore, carbendazim @ $0.1 \%$ is recommended for use against powdery mildew disease of Sesame.

\section{References}

Anonymous. Annual progress report, sesame and Niger, Project Co-ordinating Unit (Sesame and Niger), J.N.K.V.V. Campus, Jabalpur, 2015.

Bedigian D, Harlan JR. 1986. Evidence for cultivation of sesame in the ancient world. Economic Botany. 40:137-154.

Ermias Teshome. 2018. Evaluation of Different Fungicides for Effective Management of Powdery mildew (Oidium sesami) of Sesame (Sesamum indicum L.) in Southeastern Oromia; Bale, Ethiopia. Acta Scientific Agriculture. 2 (8): 18-23.

Jeyalakshmi, C., C. Rettinassababady and Sushma Nema. 2013. Integrated management of sesame diseases. Journal of Biopesticides. 6(1): 68-70.

\section{How to cite this article:}

Madhuri, V., and Karuna Sagar, G. 2018. Management of Powdery Mildew Disease in Sesamum. Int.J.Curr.Microbiol.App.Sci. 7(09): 3339-3344.

doi: https://doi.org/10.20546/ijcmas.2018.709.414 